\title{
THE EFFECT OF ACTIVITY LEVEL OF THE INTEGRATED HEALTH POST ON THE COMMUNITY HEALTH WORKERS PERFORMANCE ON CHILD GROWTH AND DEVELOPMENT HEALTH SERVICES: A MULTILEVEL ANALYSIS
}

\author{
Lidia Ekiq Kurniavie'), Pawito²), Bhisma Murti'1) \\ 1)Masters Program in Public Health, Universitas Sebelas Maret \\ ${ }^{2}$ Faculty of Social and Sciences, Universitas Sebelas Maret
}

\begin{abstract}
Background: Government support has a role in increasing health program development. Cadre performance is important because they are responsible for implementing the integrated health posts (posyandu) program, especially in monitoring the growth and development of children under five. This study aimed to examine the effect of activity level of the integrated health post on the community health workers performance on child growth and development health services

Subjects and Method: A cross-sectional study was conducted at 25 posyandus in Karanganyar, Central Java, from August to September 2019. A sample of 200 cadres was selected by stratified random sampling. The dependent variable was cadre performance. The independent variables were education, employment, knowledge, attitude, training, tenure, posyandu facilities, social support, and village government support. The data were collected by questionnaire and analyzed by a multiple logistic regression run on Stata 13 .

Results: Posyandu cadre with good performance was $50.50 \%$, had education $\geq$ Senior high school was $63 \%$, and working at home was $88 \%$. Cadre performance on child growth and development health services increased with education $\geq$ Senior high school $(b=1.27 ; 95 \% \mathrm{CI}=$ 0.24 to $2.30 ; p=0.015)$, working at home $(b=1.41 ; 95 \% \mathrm{CI}=0.39$ to $2.42 ; \mathrm{p}=0.007)$, high knowledge $(b=1.53 ; 95 \% \mathrm{CI}=0.56$ to $2.49 ; \mathrm{p}=0.002)$, positive attitude $(\mathrm{b}=1.41 ; 95 \% \mathrm{CI}=0.33$ to $2.50 ; \mathrm{p}=0.011)$, had trained $\geq 2$ times $(\mathrm{b}=1.33 ; 95 \% \mathrm{CI}=0.37$ to $2.29 ; \mathrm{p}=0.007)$, tenure $\geq 10$ years $(b=1.21 ; 95 \% C I=0.25$ to $2.18 ; p=0.014)$, good facilities $(b=1.57 ; 95 \% C I=0.54$ to 2.59 ; $\mathrm{p}=0.003)$, strong social support $(\mathrm{b}=1.28 ; 95 \% \mathrm{CI}=0.28$ to $2.29 ; \mathrm{p}=0.013)$, and strong village government support $(\mathrm{b}=1.28 ; 95 \% \mathrm{CI}=0.26$ to $2.31 ; \mathrm{p}=0.014)$. Posyandu had strong contextual effect on cadre performance on child growth and development health services with intra-class correlation (ICC) $=27.55 \%$.

Conclusion: Cadre performance on child growth and development health services increases with high education, working at home, high knowledge, positive attitude, had trained $\geq 2$ times, tenure $\geq 10$ years, good facilities, strong social support, and strong village government support. Posyandu has strong contextual effect on cadre performance on child growth and development health services.
\end{abstract}

Keywords: cadre performance, child growth and development, integrated health post, multilevel analysis

\section{Correspondence:}

Lidia Ekiq Kurniavie. Masters Program in Public Health, Universitas Sebelas Maret. Jl. Ir. Sutami 36A, Surakarta 57126, Central Java, Indonesia. Email: ekiqlkv@gmail.com. Mobile: 085852540575 . 